\title{
Pengaruh Pemberian Aspartam terhadap Kadar Low-Density Lipoprotein dan High-Density Lipoprotein pada Tikus Wistar Diabetes Melitus Diinduksi Aloksan
}

\author{
Revivo Rinda Pratama ${ }^{1}$, Eti Yerizel $^{2}$, Rahmatini $^{3}$
}

\begin{abstract}
Abstrak
Aspartam telah disetujui oleh FDA untuk dikonsumsi. Konsumsi pemanis buatan ini menggunakan dosis ADI (Acceptable Daily Intake) yaitu $50 \mathrm{mg} / \mathrm{kgBB}$. Individu dengan diabetes melitus kemungkinan menjadi antusias terhadap adanya aspartam. Aspartam dapat mempengaruhi metabolisme profil lipid. Tujuan dari penelitian ini adalah mengetahui pengaruh pemberian aspartam terhadap kadar LDL dan HDL tikus diabetes melitus diinduksi aloksan. Ini merupakan penelitian eksperimental dengan randomized post test only control group design. Subjek penelitian adalah 15 ekor tikus Wistar jantan yang dibagi menjadi tiga kelompok, yaitu kelompok kontrol negatif, kelompok kontrol positif, dan kelompok perlakuan. Masing-masing kelompok terdiri dari lima (5) ekor tikus. Pemberian aspartam (dosis 315 $\mathrm{mg} / \mathrm{kgBB}$ tikus) diberikan kepada kelompok perlakuan selama empat (4) minggu. Hasil penelitian menunjukkan bahwa pemberian aspartam pada tikus diabetes melitus diinduksi aloksan berpengaruh terhadap penurunan kadar LDL dan peningkatan kadar HDL. Kadar LDL pada kelompok kontrol positif adalah $30 \pm 2 \mathrm{mg} / \mathrm{dl}$, pada kelompok perlakuan adalah $24 \pm 2 \mathrm{mg} / \mathrm{dl}$. Sedangkan kadar HDL pada kelompok kontrol positif adalah $19 \pm 1 \mathrm{mg} / \mathrm{dl}$, pada kelompok perlakuan adalah $22 \pm 1 \mathrm{mg} / \mathrm{dl}$. Terdapat perbedaan yang bermakna pada kadar LDL dan HDL antara kelompok kontrol positif dengan kelompok perlakuan. Kesimpulan hasil penelitian ini adalah pemberian aspartam pada tikus diabetes melitus diinduksi aloksan berpengaruh terhadap penurunan kadar LDL dan peningkatan kadar HDL.
\end{abstract}

Kata kunci: aspartam, diabetes melitus, LDL, HDL

\begin{abstract}
Aspartame has been approved by the FDA for consumption. Consumption of artificial sweeteners is using ADI (Acceptable Daily Intake) dose which is $50 \mathrm{mg} / \mathrm{kg}$. Individuals with diabetes mellitus would likely be enthusiastic consumers of aspartame. Aspartame can influence the metabolism of lipid profile. The purpose of this study was to determine the effect of aspartame on levels of $L D L$ and HDL at rats with diabetes mellitus induced by alloxan. The research is experimental research with randomized post test only control group design. The subjects were 15 male Wistar rats those were divided into three groups: a negative control group, a positive control group, and the treated group. Each group consists of five (5) male rats. Administration of aspartame (dose of $315 \mathrm{mg} / \mathrm{kg}$ rat) was administered to the treatment group for four (4) weeks. The results showed that administration of aspartame in rats with diabetes mellitus induced by alloxan was influenced the decreased in LDL levels and increased in HDL levels. The $L D L$ levels in positive control group was $30 \pm 2 \mathrm{mg} / \mathrm{dl}$, in the treatment group was $24 \pm 2 \mathrm{mg} / \mathrm{dl}$. While the levels of $H D L$ in positive control group was $19 \pm 1 \mathrm{mg} / \mathrm{dl}$, in the treatment group was $22 \pm 1 \mathrm{mg} / \mathrm{dl}$. There is a significant difference in the levels of LDL and HDL between the positive control group with the treatment group. The conclusion of this research are the administration of aspartame in rats with diabetes mellitus induced by alloxan influenced the decreased in LDL levels and increased in HDL levels.
\end{abstract}

Keywords: aspartame, diabetes mellitus, $L D L, H D L$ 
Affiliasi penulis : 1.Pendidikan Dokter FK UNAND (Fakultas Kedokteran Universitas Andalas Padang), 2. Bagian Biokimia FK UNAND, 3. Bagian Farmakologi FK UNAND

Korespondensi :RevivoRindaPratama,

Email : revivorinda@gmail.com, telp: 081268123492

\section{PENDAHULUAN}

Pemanis buatan adalah suatu zat dari beberapa kelas bahan kimia berbeda yang berinteraksi dengan reseptor rasa sehingga menimbulkan rasa manis 30 sampai 13.000 kali yang melebihi sukrosa dan tanpa kalori atau rendah kalori. ${ }^{1}$ Menurut Sahstry $d k k$, dengan kuatnya rasa manis yang dihasilkan sehingga pemanis tersebut hanya dibutuhkan dalam jumlah minimal dengan menggunakan dosis ADI (Acceptable Daily Intake) yaitu dosis harian suatu zat yang dapat dikonsumsi tiap kilogram berat badan selama seumur hidup tanpa menimbulkan resiko pada tubuh. ${ }^{2,3}$

FDA (Food and Drug Administration) telah menyetujui beberapa pemanis buatan untuk dikonsumsi. Pemanis tersebut adalah asesulfam-K, aspartam, neotam, sakarin, dan sukralosa. Diantara pemanis tersebut yang paling banyak digunakan adalah aspartam, sukralosa, dan asesulfam-K. ${ }^{2}$

Salah satu pemanis buatan yang telah mengalami uji menyeluruh dan telah disetujui oleh FDA adalah aspartam. Sejak tahun 1981, aspartam telah diizinkan untuk dipasarkan di Amerika Serikat kemudian penggunaan aspartam sebagai pemanis bahan makanan kering telah diizinkan sebelumnya pada tahun 1974 sedangkan penggunaannya dalam minuman segar, dikeluarkan pada tahun $1983 .^{3}$ Dalam penggunaannya, FDA di Amerika menetapkan dosis ADI aspartam adalah $50 \mathrm{mg} / \mathrm{kgBB}^{4} \mathrm{Di}$ Indonesia, penggunaan aspartam diizinkan dalam Peraturan Menteri Kesehatan Republik Indonesia nomor 722/Menkes/Per/IX/1988 tentang Bahan Tambahan Makanan. Dalam mengonsumsi pemanis ini, BPOM menetapkan dosis ADI aspartam di Indonesia adalah $50 \mathrm{mg} / \mathrm{kgBB}^{5}$

Aspartam terdiri dari asam amino sehingga $d$ dalam tubuh akan mengalami metabolisme menjadi 2 asam amino (asam aspartat dan L-fenilalanin) dan metanol. Hasil penguraian 2 asam amino dan metanol ini tidak akan menimbulkan efek yang berbahaya pada tubuh, oleh karena itu, aspartam merupakan salah satu bahan makanan yang aman bagi penderita diabetes melitus. ${ }^{3}$

Individu dengan diabetes melitus kemungkinan akan menjadi konsumen yang antusias terhadap adanya aspartam. ${ }^{4}$ Diabetes melitus merupakan suatu kelompok penyakit metabolik dengan karakteristik hiperglikemia. Kondisi hiperglikemia ini terjadi karena kelainan sekresi insulin, kerja insulin, atau kedua-duanya yang berhubungan dengan kerusakan jangka panjang, disfungsi, atau kegagalan beberapa organ tubuh. ${ }^{6}$

Diabetes melitus telah dikategorikan sebagai penyakit global oleh WHO dengan jumlah penderita di dunia mencapai 199 juta jiwa pada tahun 2009. Selain itu, pada tahun 2011, IDF menyatakan bahwa 366 juta orang di dunia menderita diabetes melitus pada tahun 2011 dan diproyeksikan akan meningkat menjadi 552 juta jiwa pada tahun 2030. Indonesia merupakan negara kesepuluh dengan jumlah penderita diabetes melitus terbanyak di dunia pada tahun $2011 .{ }^{7}$

Adanya defisiensi atau resistensi insulin yang terjadinya pada proses timbulnya diabetes melitus menyebabkan peningkatan stres oksidatif. Keadaan ini dapat mengakibatkan gangguan metabolisme lipoprotein (dislipidemia) yang merupakan salah satu komponen sindrom metabolik. Gangguan metabolisme lipoprotein ini ditandai dengan peningkatan trigliserida, peningkatan small dense LDL yang bersifat aterogenik, dan penurunan kolesterol HDL, yang disebut lipid triad. ${ }^{8,9}$

Beberapa penelitian mengenai keterkaitan aspartam dengan kadar glukosa darah dan komponen profil lipid diantaranya LDL dan HDL dimana hasilnya masih terdapat perbedaan dalam pengaruh kadar glukosa darah dan profil lipid tersebut. Dalam penelitian Institute of Pharmaceutical Sciences, Nitte University di India pada tahun 2012 menunjukkan bahwa pemanis buatan ini tidak sepenuhnya aman. Di sisi lain, hasil yang sangat bertolak belakang dengan penelitian sebelumnya pada tahun 1984 sampai 1986 yang menunjukkan bahwa konsumsi aspartam aman digunakan. Berdasarkan kedua hasil ini, keamanan untuk mengonsumsi pemanis buatan ini pada penderita diabetes melitus masih kontroversial 
walaupun telah disetujui FDA. ${ }^{1}$

Berdasarkan hal yang dijelaskan diatas, dilakukanlah penelitian ini untuk membuktikan pengaruh pemberian aspartam terhadap perubahan kadar LDL dan HDL pada tikus diabetes melitus. Pemilihan kadar LDL dan HDL ini, dikaitkan dengan sindrom metabolik, apakah penderita diabetes melitus akan menjadi dislipidemia yang merupakan salah satu dari sindrom metabolik serta apakah aspartam masih layak dikonsumsi oleh penderita diabetes melitus sebagai pengganti pemanis. Penelitian ini bertujuan untuk mengetahui pengaruh pemberian aspartam terhadap kadar LDL dan HDL pada tikus diabetes melitus diinduksi aloksan.

\section{METODE}

Metode yang digunakan adalah eksperimental dengan rancangan randomized post test only control group design untuk mengetahui pengaruh pemberian aspartam terhadap kadar LDL dan HDL pada tikus putih strain Wistar diabetes melitus setelah diinduksi aloksan. Subjek penelitian adalah tikus putih (Rattus norvegicus) Jantan Strain Wistar.

Jumlah tikus yang dipakai sebagai subjek sesuai dengan kriteria World Health Organization (WHO), yaitu minimal lima (5) ekor tikus pada setiap kelompok. $^{10}$

Subjek penelitian adalah 15 ekor tikus Wistar, yang dibagi menjadi tiga kelompok, yaitu Kelompok KN sebagai kelompok kontrol negatif, Kelompok KP sebagai kelompok kontrol positif, dan Kelompok $\mathrm{P}$ sebagai kelompok perlakuan. Kelompok KN tidak diberi perlakuan, kelompok KP diinduksi aloksan, dan kelompok $\mathrm{P}$ diinduksi aloksan dan diberi aspartam. Pemilihan sampel dan pengelompokkannya dilakukan secara acak.

Kriteria inklusi adalah tikus Wistar jantan sehat, berumur 2-3 bulan pada saat pemilihan sampel dengan berat badan 150-250 gram dan dalam keadaan diabetes setelah dinduksi aloksan. Kriteria eksklusi adalah tikus Wistar sakit.

Variabel independen adalah pemberian aspartam. Pemberian aspartam dengan dosis 315 $\mathrm{mg} / \mathrm{kgBB}$ tikus dengan teknik gavage oral pada kelompok perlakuan. Variabel dependen terdiri dari kadar LDL dan HDL diukur dengan spektofotometer.

Aklimatisasi terhadap hewan dilakukan selama 7 hari untuk membiasakan hewan pada kondisi percobaan dan diberi makanan standar serta minuman yang cukup. Setiap kelompok diberikan makanan yang sama.

Kelompok KP dan $\mathrm{P}$ kemudian diinduksi aloksan dengan dosis $150 \mathrm{mg} / \mathrm{kgBB}$ secara intraperitoneal. Setelah tiga hari, dilakukan pemeriksaan kadar glukosa darah untuk mengetahui apakah tikus telah mengalami keadaan diabetes melitus (>135 mg/dl). ${ }^{11}$

Setelah tikus mengalami diabetes melitus, kelompok $P$ diberi aspartam dengan dosis $A D I$ tikus yaitu $315 \mathrm{mg} / \mathrm{kgBB} /$ hari setelah dikonversi dari dosis ADI manusia. Aspartam serbuk dilarutkan dengan air. Pemberian aspartam dilakukan melalui teknik gavage oral untuk memastikan agar tidak ada yang terbuang atau tersisa. Teknik gavage oral merupakan teknik pemberian kepada hewan coba melalui rongga mulut dengan menggunakan spuit dan jarum suntik tumpul. Perlakuan ini diberikan selama 4 (empat) minggu.

Setelah empat minggu perlakuan, masingmasing kelompok dilakukan pengukuran kadar LDL dan HDL. Sebelum pengukuran, tikus dipuasakan selama 8-10 jam. Selanjutnya darah diambil di sinus retro orbital kemudian disentrifugasi pada $4000 \mathrm{rpm}$. Serum dipisahkan dan profil lipid yaitu LDL dan HDL diukur menggunakan spektofotometer dengan metode enzimatik.

Hasil pengukuran kadar LDL dan HDL tikus dicatat, ditabulasi, dan dianalisis secara statistik menggunakan program SPSS versi 22.0. Analisis data terhadap perubahan kadar LDL dan HDL dilakukan melalui uji hipotesis komparatif secara bertahap, yaitu uji normalitas data (Shapiro-Wilks), uji homogenitas varian, uji One-Way ANOVA diikuti PostHoc test (uji Least Significant Difference) dengan alternatif uji non-parametrik Kruskal-Wallis. Rerata (mean) dan simpangan baku (standard deviation) untuk tiap kelompok dihitung dari data yang didapatkan. Nilai yang didapat dari data hasil penelitian akan disajikan dalam bentuk rerata (mean) \pm standar deviasi (SD). 
HASIL

Hasil pengukuran kadar LDL pada kelompok kontrol negatif didapatkan rerata sebesar $27 \mathrm{mg} / \mathrm{dl}$. Kelompok kontrol positif yang diinduksi aloksan memiliki kadar LDL sebesar $30 \mathrm{mg} / \mathrm{dl}$. Dari hasil pemeriksaan terdapat peningkatan kadar LDL, dimana kadar LDL kontrol positif lebih tinggi dari kadar LDL kontrol negatif. Rerata kadar LDL pada kelompok perlakuan dengan pemberian aspartam adalah 24 $\mathrm{mg} / \mathrm{dl}$, terjadi penurunan kadar LDL jika dibandingkan dengan kontrol positif (tabel 1).

Hasil pengukuran kadar HDL pada kelompok kontrol negatif didapatkan rerata sebesar $22 \mathrm{mg} / \mathrm{dl}$. Kelompok kontrol positif yang diinduksi aloksan memiliki kadar HDL sebesar $19 \mathrm{mg} / \mathrm{dl}$. Dari hasil pemeriksaan terdapat penurunan kadar HDL, dimana kadar HDL kontrol positif lebih rendah dari kadar HDL kontrol negatif. Rerata kadar HDL pada kelompok perlakuan dengan pemberian aspartam adalah 22 $\mathrm{mg} / \mathrm{dl}$, terjadi peningkatan kadar HDL jika dibandingkan dengan kontrol positif (tabel 2).

Pada analisis data dilakukan uji analisis berupa ujiShapiro-Wilk untuk mengetahui distribusi data normal atau tidak, uji homogenitas varian untuk mengetahui varians data sama atau tidak, ujiOne-Way ANOVA untuk mengetahui terdapat perbedaan bermakna pada dua kelompok, diikuti Post-Hoc test (uji Least Significant Difference) untuk mengetahui antar kelompok mana yang terdapat perbedaan bermakna. $^{12}$

Analisis kadar LDL dilakukan dengan uji analisis berupa uji Shapiro-Wilk, didapatkan nilai p>0,05 pada ketiga kelompok yang menyatakan distribusi data normal (tabel 3). Selanjutnya dilakukan uji homogenitas varians, didapatkan nilai $p>0,05$ yang artinya varians data sama. Pengujian data dilanjutkan ke uji One-Way ANOVA, didapatkan $p=0,000(p<0,05)$ yang menunjukkan terdapat perbedaan bermakna pada dua kelompok. Uji analisis dilanjutkan dengan uji Post-hoc, didapatkan $\mathrm{p}<0,05$ yang menunjukkan terdapat perbedaan bermakna antara kelompok kontrol negatif dengan kelompok kontrol positif, kelompok kontrol positif dengan kelompok perlakuan, dan kelompok kontrol negatif dengan kelompok perlakuan (tabel 4).
Analisis kadar HDL dilakukan dengan uji analisis berupa uji Shapiro-Wilk, didapatkan nilai $p>0,05$ pada ketiga kelompok yang menyatakan distribusi data normal (tabel 5). Selanjutnya dilakukan uji homogenitas varians, didapatkan nilai $p>0,05$ yang artinya varians data sama. Pengujian data dilanjutkan ke uji One-Way ANOVA, didapatkan $p=0,001(p<0,05)$ yang menunjukkan terdapat perbedaan bermakna pada dua kelompok. Uji analisis dilanjutkan dengan uji Post-hoc, didapatkan $\mathrm{p}<0,05$ yang menunjukkan terdapat perbedaan bermakna antara kelompok kontrol negatif dengan kelompok kontrol positif dan kelompok kontrol positif dengan kelompok perlakuan (tabel 6).

\section{PEMBAHASAN}

Berdasarkan hasil pada tabel 1, terjadi peningkatan kadar LDL pada kelompok control positif tikus yang diinduksi aloksan disbanding kadar LDL kelompok kontrol negatif yang normal. Pada uji analisis terdapat perbedaan yang bermakna kadar LDL antara kedua kelompok kontrol tersebut. Hal ini terjadi karena pada keadaan hiperglikemia yang disebabkan oleh defisiensi insulin atau resistensi insulin pada diabetes mellitus mengakibatkan peningkatan kadar LDL yang disebabkan karena kelainan metabolisme LDL. Akibat kelainan metabolisme tersebut terjadi pengaktifan hormone sensitive lipase di jaringan adipose mengakibatkan terjadi peningkatan lipolisis trigliserida di jaringan adipose sehingga menghasilkan asam lemak bebas yang berlebihan. Kadar asam lemak bebas yang berlebihan ini menyebabkan terbentuknya small dense LDL yang mudah teroksidasi sehingga bersifat aterogenik. $^{13}$

Rerata kadar LDL pada kelompok perlakuan mengalami penurunan terhadap kelompok control positif. Pada uji analisis, penurunan kadar LDL antara kelompok control positif dengan kelompok perlakuan menunjukkan perbedaan yang bermakna dengan nilai $p<0,05$. Hal ini menunjukkan bahwa pemberian aspartame memberikan efek menurunkan kadar LDL secara bermakna pada keadaan diabetes melitus. Hasil penelitian ini, didapatkan penurunan kadar LDL setelah pemberian aspartam pada tikus yang diinduksi 
aloksan, berbeda dengan hipotesis yaitu terjadi peningkatan kadar LDL setelah pemberian aspartam. Hal ini terjadi karena aspartame dapat meningkatkan jumlah reseptor LDL di membran sel. ${ }^{14}$ Peningkatan jumlah reseptor LDL tersebut membawa LDL darah ke dalam sel untuk mengalami proses endositosis sehingga terjadi penurunan kadar LDL dalam darah. ${ }^{15}$

Berdasarkan hasil pada tabel 2, terjadi penurunan kadar HDL pada kelompok kontrol positif tikus yang diinduksi aloksan disbanding kadar HDL kelompok kontrol negatif yang normal. Pada uji analisis, terdapat perbedaan yang bermakna antara kedua kelompok kontrol tersebut. Hal ini terjadi karena keadaan resistensi insulin atau defisiensi insulin pada diabetes mellitus menyebabkan hormone sensitive lipase di jaringan adipose menjadi aktif sehingga meningkatkan lipolisis trigliserida di jaringan adiposa. Keadaan ini menghasilkan asam lemak bebas yang berlebihan kemudian dibawa ke hati sebagai bahan baku pembentukan trigliserida. Pembentukan trigliserida ini merupakan bagian dari VLDL yang dihasilkan pada keadaan hiperglikemia sangat kaya trigliserida yang disebut sebagai VLDL besar. VLDL ini bertukar dengan kolesterol ester dari HDL sehingga menghasilkan HDL yang miskin kolesterol ester tapi kaya trigliserida. HDL dalam bentuk ini lebih mudah mengalami katabolisme oleh ginjal sehingga jumlah HDL serum menurun. ${ }^{13}$

Rerata kadar HDL pada kelompok perlakuan mengalami peningkatan terhadap kelompok control positif. Pada uji analisis, peningkatan kadar HDL antara kelompok kontrol positif dengan kelompok kontrol perlakuan menunjukkan perbedaan yang bermakna dengan nilai $p<0,05$. Hal ini menunjukkan bahwa pemberian aspartam memberikan efek dalam meningkatkan kadar HDL secara bermakna pada keadaan diabetes melitus. Hasil penelitian ini, didapatkan peningkatan kadar HDL setelah pemberian aspartam pada tikus yang diinduksi aloksan, berbeda dengan hipotesis yaitu terjadi penurunan kadar HDL setelah pemberian aspartam. Terdapat faktor yang menyebabkan terjadinya peningkatan kadar HDL diantaranya aspartam dapat meningkatkan kadar apo
A-I yang merupakan komponen protein utama HDL, karena pada resistensi insulin terjadi penurunan kadar apo A-I. ${ }^{16} \mathrm{Hal}$ ini menyebabkan kadar HDL meningkat karena komposisi dominan dari HDL adalah protein. ${ }^{15}$

\section{KESIMPULAN}

Berdasarkan hasil penelitian tentang pengaruh pemberian aspartam terhadap kadar LDL dan HDL padatikus diabetes melitus yang diinduksi aloksan, maka dapat diambil beberapa kesimpulan:

1. Pemberian aspartam dengan dosis ADI 315 $\mathrm{mg} / \mathrm{kgBB} /$ hari menyebabkan penurunan kadar LDL terhadap tikus diabetes melitus diinduksi aloksan.

2. Pemberian aspartam dengan dosis ADI 315 $\mathrm{mg} / \mathrm{kgBB} /$ hari menyebabkan peningkatan kadar HDL terhadap tikus diabetes melitus diinduksi aloksan.

TABEL

Tabel 1. Nilai Rerata Kadar LDL (mg/dl)

\begin{tabular}{ccc}
\hline Kelompok & $\mathbf{n}$ & Rerata \pm SD \\
\hline Kontrol Negatif & 5 & $27 \pm 1$ \\
Kontrol Positif & 5 & $30 \pm 2$ \\
Perlakuan & 5 & $24 \pm 2$
\end{tabular}

Keterangan tabel:

$\mathrm{n} \quad$ : jumlah hewan percobaan

Tabel 2. Nilai Rerata Kadar HDL (mg/dl)

\begin{tabular}{ccc}
\hline Kelompok & $\mathbf{n}$ & Rerata \pm SD \\
\hline Kontrol Negatif & 5 & $22 \pm 1$ \\
Kontrol Positif & 5 & $19 \pm 1$ \\
Perlakuan & 5 & $22 \pm 1$
\end{tabular}

Keterangan tabel:

$\mathrm{n} \quad$ : jumlah hewan percobaan

Tabel 3. Uji Shapiro-Wilk pada Hasil Pengukuran LDL

\begin{tabular}{llcc}
\hline & Kelompok Hewan Coba & n & p \\
\hline \multirow{2}{*}{ LDL } & Kontrol Negatif & 5 & 0,755 \\
\cline { 2 - 3 } & Kontrol Positif & 5 & 0,769 \\
& Perlakuan & 5 & 0,874
\end{tabular}

Keterangan tabel:

n : jumlah hewan percobaan

p : nilai probabilitas 
Tabel 4. Uji Post-hoc pada Hasil Pengukuran LDL

\begin{tabular}{cccc}
\hline Kelompok & $\begin{array}{c}\text { Kontrol } \\
\text { Negatif }\end{array}$ & $\begin{array}{c}\text { Kontrol } \\
\text { Positif }\end{array}$ & Perlakuan \\
\hline Kontrol & - & $0,006^{*}$ & $0,002^{*}$ \\
Negatif & & - & $<0,05^{\star}$ \\
Kontrol & $0,006^{*}$ & & \\
$\begin{array}{c}\text { Positif } \\
\text { Perlakuan }\end{array}$ & $0,002^{*}$ & $<0,05^{*}$ & - \\
\hline
\end{tabular}

Keterangan tabel:

* : perbedaan bermakna $(p<0,05)$ yaitu:

- Kelompok kontrol negatif vs kontrol positif

- Kelompok kontrol positif vs perlakuan

- Kelompok kontrol negatif vs perlakuan

Tabel 5. Uji Shapiro-Wilk pada Hasil Pengukuran HDL

\begin{tabular}{llcc}
\hline & Kelompok Hewan Coba & n & p \\
\hline \multirow{3}{*}{ LDL Kontrol Negatif } & Kontrol Positif & 5 & 0,603 \\
\cline { 2 - 3 } & Perlakuan & 5 & 0,860 \\
& 5 & 0,607
\end{tabular}

Keterangan tabel:

n : jumlah hewan percobaan

p : nilai probabilitas

Tabel 6. Uji Post-hoc pada Hasil Pengukuran HDL

\begin{tabular}{cccc}
\hline Kelompok & $\begin{array}{c}\text { Kontrol } \\
\text { Negatif }\end{array}$ & $\begin{array}{c}\text { Kontrol } \\
\text { Positif }\end{array}$ & Perlakuan \\
\hline $\begin{array}{c}\text { Kontrol } \\
\text { Negatif }\end{array}$ & - & $0,001^{*}$ & 0,899 \\
$\begin{array}{c}\text { Kontrol } \\
\text { Positif }\end{array}$ & $0,001^{*}$ & - & $0,001^{*}$ \\
Perlakuan & 0,899 & $0,001^{*}$ & - \\
\hline
\end{tabular}

Keterangan tabel:

* : perbedaan bermakna $(p<0,05)$ yaitu:

- Kelompok kontrol negatif vs kontrol positif

- Kelompok kontrol positif vs perlakuan

\section{UCAPAN TERIMA KASIH}

Ucapan terima kasih kepada DR. Eti Yerizel, Dra, MS dan dr. Rahmatini, M.Kes yang telah banyak memberikan bimbingan, bantuan dan motivasi dalam penelitian ini.

\section{DAFTAR PUSTAKA}

1 Erina, EVH. Artificial sweeteners: their origin and mechanism. 2009 (diunduh 3 Februari 2013). Tersedia dari: URL: HYPERLINK
http://www.clfs.umd.edu/grad/mlfsc/Artific ial\%20sweeteners.pdf

2 Shastry CS, Yatheesh CK, Aswathanarayana BJ. Comparattive evaluation of diabetogenic and mutagenic potential of artificial sweeteners- aspartame, acesulfame-K and sucralose. Nitte University Journal of Health Science. 2012;2(3):80-1.

3 Cahyadi W. Analisis \& aspek kesehatan bahan tambahan makanan. Edisi ke-2. Bandung: Bumi Aksara; 2009.

4 Butchko, et al. Aspartame: review of safety endocrine evaluations with aspartame. USA: Elsevier Science; 2002.

5 BPOM (Badan Pengawas Obat dan Makanan Republik Indonesia). Aspartam dalam minuman berenergi. 2012. (diunduh 20 November 2013). Tersedia dari: URL: HYPERLINK http://www.ik.pom.go.id

6 Sudoyo AW, Setiyohadi B, Alwi I, Simadibrata $M$, Setiati $S$, editor (penyunting). Buku ajar ilmu penyakit dalam. Edisi IV. Jilid III. Jakarta: Pusat Penerbitan Departemen IImu Penyakit Dalam FKUI; 2007.

7 International Diabetes Federation. The Global Burden. Brussels: International Diabetes Federation. 2011 (diunduh 21 Oktober 2012). Tersedia dari: URL: HYPERLINK http://www.idf. org/diabetesatlas/5e/the-global-burden

8 Purnamasari D, Soegondo S. Sindrom metabolik. Dalam: Sudoyo A W, Setiyohadi B, Alwi I, Simadibrata M, Setiadi S, editor (penyunting). Buku ajar ilmu penyakit dalam. Edisi Kelima. Jilid III. Jakarta: Pusat Penerbitan Departemen IImu Penyakit Dalam FKUI; 2010. hlm. 1867.

9 Shahab A. Komplikasi kronik DM penyakit jantung koroner. Dalam: Sudoyo AW, Setiyohadi B, Alwi I, 
Simadibrata $M$, Setiadi $S$, editor (penyunting). Buku Ajar IImu Penyakit Dalam. Edisi Kelima. Jilid III. Jakarta: Pusat Penerbitan Departemen IImu Penyakit Dalam FKUI; 2010. hlm. 1939.

10 World Health Organization. General guidelines for methodologies on research and evaluation of traditional medicine. 2000.

11 Wulandari CE. Pengaruh pemberian ekstrak bawang merah terhadap penurunan kadar glukosa darah pada tikus wistar dengan hiperglikemia. (Artikel karya tulis ilmiah). Semarang:Universitas Diponegoro; 2010.

12 Dahlan MS. Statistik untuk kedokteran dan kesehatan. Edisi ke-5. Jakarta: Salemba Medika; 2013.

13 Adam, John MF. Dislipidemia. Dalam: Sudoyo A W, Setiyohadi B, Alwi I,
Simadibrata $M$, Setiadi $S$, editor (penyunting). Buku Ajar IImu Penyakit Dalam. Edisi ke-5. Jilid III. Jakarta: Pusat Penerbitan Departemen IImu Penyakit Dalam FKUI; 2010. hlm. 1991.

14 Collison KS, et al. Nutrition and metabolism. Saudi Arabia: Biomed Central Ltd.2013; 10: 6-7.

15 Marks DB, Smith CM. Biokimia kedokteran Dasar (terjemahan). Jakarta: Penerbit EGC; 2000.

16 Jang W, Jeoung NM, Cho K. 2011. Modified apolipoprotein (apo) a-i by artificial sweetener causes severe premature cellular senescence and atherosclerosis with impairment of functional and structural properties of ApoA-I in lipid-free and lipid-bound state. Korea: Springer. 2011 May (diunduh 19 Desember 2013). Tersedia dari: URL: HYPERLINK http://www.molcells.org. 